\title{
Influence of storage conditions of alginate mass impressions on their spatial dimensions
}

\section{Wpływ warunków przechowywania wycisków wykonanych masą alginatową na ich wymiary przestrzenne}

\author{
Marcin Szerszeń ${ }^{1}$, Daniel Surowiecki ${ }^{2}$, Michat Tyrajski ${ }^{2}$ \\ ${ }^{1}$ Katedra Protetyki Stomatologicznej, Warszawski Uniwersytet Medyczny \\ Department of Prosthodontics, Medical University of Warsaw \\ ${ }^{2}$ Studenckie Koło Naukowe, Katedra Protetyki Stomatologicznej, Warszawski Uniwersytet Medyczny \\ Students' Research Group, Department of Prosthodontics, Medical University of Warsaw \\ Head: prof. dr hab. n. med. Elżbieta Mierzwińska-Nastalska
}

KEY WORDS:

alginate masses, dental impression, storage conditions

\section{Summary}

Introduction. Alginate masses, due to their numerous advantages, are often used as an impression material in prosthetic treatment. Storage conditions of alginate impressions are crucial for stability of its dimensions. The development of technologies used in modern dental prosthetics determines search for the highest possible accuracy and predictability in representation of prosthetic field. In everyday practice, prosthetic laboratories are rarely a part of dental offices, what makes reasonable to determine the optimal conditions for storing impressions made with alginate masses.

Aim of the study. To determine the influence of storage conditions of alginate mass impressions on their spatial dimensions.

Materials and Methods. Forty cubic alginate samples were made and divided into 8 groups. Each group of samples was stored in a diverse environment of temperature and humidity. Storage conditions were controlled by digital hytherographs. The spatial dimensions of samples were measured using an electronic vernier caliper with

\section{HASŁA INDEKSOWE:}

masy alginatowe, wyciski dentystyczne, warunki przechowywania

\section{Streszczenie}

Wstęp. Masy alginatowe, ze względu na liczne zalety, często wykorzystywane sa jako materiat wyciskowy $w$ leczeniu protetycznym. Warunki przechowywania wycisku alginatowego sa kluczowe dla stabilności jego wymiarów. Rozwój technologii stosowanych $w$ nowoczesnej protetyce stomatologicznej determinuje poszukiwanie możliwie jak największej dokładności i przewidywalności $w$ odwzorowaniu pola protetycznego. $W$ codziennej praktyce lekarza dentysty rzadko spotyka sie laboratoria protetyczne przy gabinetach, co czyni zasadnym podjęcie próby ustalenia optymalnych warunków przechowywania wycisków wykonanych przy uzyciu mas alginatowych.

Cel pracy. Celem pracy byto określenie wptywu warunków przechowywania wycisków wykonanych masa alginatowa na ich wymiary przestrzenne.

Material i metoda. Wykonano 40 sześciennych próbek z masy alginatowej, które podzielono na 8 grup. Każda grupa próbek przechowywana byta w zróżnicowanym środowisku pod względem temperatury $i$ wilgotności. Warunki przechowywania 
an accuracy of $\pm 0.02 \mathrm{~mm}$, immediately after setting time of alginate mass and after 24 and 144 hours of storage. The results of the measurements were analyzed using descriptive statistics as well as Kruskall-Wallis test.

Results. The smallest change of the dimensions of tested samples was observed in the group stored in humidity of $65 \%$ and at a temperature of $7.5^{\circ} \mathrm{C}$ (after 24 hours) and $24.4^{\circ} \mathrm{C}$ (after 144 hours). The largest dimensional change was noted in groups stored without increased humidity values and in the alcohol-based solution of the disinfecting liquid.

Conlusions. 1. Increased humidity ensures the smallest change of the dimensions of impressions taken using alginate mass. 2. Lowering the storage temperature positively influences the dimensions of the tested samples. 3. Alcohol-based disinfectants should not be used for storing alginate impressions because they reduce the size of the tested samples.

\section{Introduction}

Despite dynamic development of technologies used in modern dental prosthetics, such as digital work using laboratory or intraoral scanning,,$^{1,2}$ and implementation of a range of improved impression materials, ${ }^{3,4}$ alginate masses that have been used for years still have a wide clinical application and remain the gold standard at the initial stages of treatment planning or as a relatively cheap and timesaving method of prosthetic field imaging. However, considering the development of the aforementioned technologies, determining the ever more accurate and predictable treatment results, including the application of alginate masses, requires conditions to ensure correction of the inaccuracy error connected with taking kontrolowane byty przez cyfrowe termohigrometry. Wymiary przestrzenne próbek zostaly zmierzone przy pomocy elektronicznej suwmiarki o dokładności pomiaru $\pm 0,02 \mathrm{~mm}$, bezpośrednio po zwiazaniu masy alginatowej oraz po 24 i 144 godzinach przechowywania. Wyniki pomiarów zostaty przeanalizowane stosujac statystyke opisowa, a także przy użyciu testu Kruskalla - Wallisa.

Wyniki. Najmniejsza zmianę wymiarów badanych próbek zaobserwowano $w$ grupie przechowywanej $w$ wilgotności $65 \%$ oraz $w$ temperaturze $7,5^{\circ} \mathrm{C}$ (po 24 godzinach) oraz $24,4^{\circ} \mathrm{C}$ (po 144 godzinach). Największa zmiana wymiarów została odnotowana $w$ grupach przechowywanych bez zwiększonych wartości wilgotności oraz $w$ alkoholowym roztworze płynu dezynfekcyjnego.

Wnioski. 1. Zwiększona wilgotność zapewnia najmniejsza zmianę wymiarów wycisków wykonanych przy użyciu masy alginatowej. 2. Obnizenie temperatury przechowywania wplywa pozytywnie na wymiary badanych próbek. 3. Roztwory dezynfekcyjne na bazie alkoholu nie powinny być stosowane do przechowywania wycisków alginatowych, ponieważ powoduja zmniejszenie wymiaru badanych próbek.

\section{Wstęp}

Mimo dynamicznego rozwoju technologii stosowanych w nowoczesnej protetyce stomatologicznej, takich jak praca cyfrowa $\mathrm{z}$ wykorzystaniem skanowania laboratoryjnego czy wewnątrzustnego, ${ }^{1,2}$ a także wdrażaniu szeregu udoskonalonych materiałów wyciskowych, 3,4 wciąż szerokie zastosowanie kliniczne mają znane od lat masy alginatowe, pozostające złotym standardem na wstępnych etapach planowania leczenia, czy jako relatywnie tania i mało czasochłonna metoda odwzorowania pola protetycznego w wykonawstwie wielu uzupełnień protetycznych. Jednak zważając na rozwój wspomnianych wyżej technologii, determinujących coraz większą dokładność i przewidywalność wyników leczenia, również 
impressions. Based on the literature and clinical experience, it can be concluded that the conditions under which the alginate impression is stored and transported are an important issue. 5,6 The literature describes a variety of methods for storing impressions, both in increased humidity and modified temperature. ${ }^{7}$ It is worth noting that many studies investigate the effect of disinfectant solutions on the properties of alginate mass, ${ }^{8,9}$ whose use becomes obligatory due to cross-contamination control. On the basis of the above-mentioned information, it is advisable to examine dimensions of this mass depending on the storage conditions taking into account temperature and humidity modifications as well as long-term effect of alcohol disinfectant solutions.

\section{Aim}

To investigate the following issues:

1. Does the variation of storage conditions affect the dimensions of the tested samples made from alginate mass?

2. To what extent does humidity affect the parameters of the tested samples?

3. What is the influence of the storage temperature on the dimensions of the examined samples?

\section{Materials and methods}

Asilicone form was prepared for making cubic blocks. The form was filled with Hydrogum 5 (Zhermack, Italy) alginate mass made in the proportion recommended by the manufacturer (Fig. 1). In this way, forty alginate samples were created, subsequently divided into eight groups relative to their storage environment. Dimensions of the cubes were measured using an electronic vernier caliper, with an accuracy of $\pm 0.02 \mathrm{~mm}$ (Fig. 2). Storage conditions humidity, room temperature and temperature in the refrigerator, were controlled by two digital zastosowanie mas alginatowych powinno odbywać się w warunkach zapewniających zniwelowanie błędu niedokładności przy pobieraniu wycisku. Na podstawie piśmiennictwa i doświadczeń klinicznych można stwierdzić, że bardzo istotną kwestią są warunki, w jakich przechowywany $\mathrm{i}$ transportowany jest wycisk alginatowy. ${ }^{5,6} \mathrm{~W}$ piśmiennictwie opisywane są wielorakie metody przechowywania wycisków zarówno w zwiększonej wilgotności, jak i w modyfikowanej temperaturze. ${ }^{7}$ Co warte uwagi, wiele badań analizuje wpływ roztworów dezynfekcyjnych na właściwości masy alginatowej, ${ }^{8,9}$ których użycie staje się czynnością obligatoryjną ze względu na kontrolę zakażeń krzyżowych. Na podstawie wyżej wymienionych informacji celowe jest zbadanie zmiany wymiarów tej masy w zależności od warunków jej przechowywania, uwzględniając modyfikację temperaturą, wilgotnością, a także długotrwały wpływ alkoholowego roztworu do dezynfekcji.

\section{Cel pracy}

1. Czy zróżnicowane warunki przechowywania wpływają na wymiary badanych próbek wykonanych $\mathrm{z}$ masy alginatowej?

2. Na ile wilgotność otoczenia wpływa na parametry badanych próbek?

3. Jaki jest wpływ temperatury przechowywania na wymiary badanych próbek?

\section{Material i metoda}

Przygotowano formę silikonową, służącą do wykonania sześciennych bloczków. Formę wypełniano masą alginatową Hydrogum 5 (Zhermack, Włochy), zarabianą w proporcji zaleconej przez producenta (ryc. 1). Wykonano w ten sposób 40 alginatowych próbek, które podzielono na 8 grup, ze względu na środowisko ich przechowywania. Wymiary kostek zostały 




Fig. 1. Preparation of alginate mass samples.

Ryc. 1. Przygotowanie próbek z masy alginatowej.

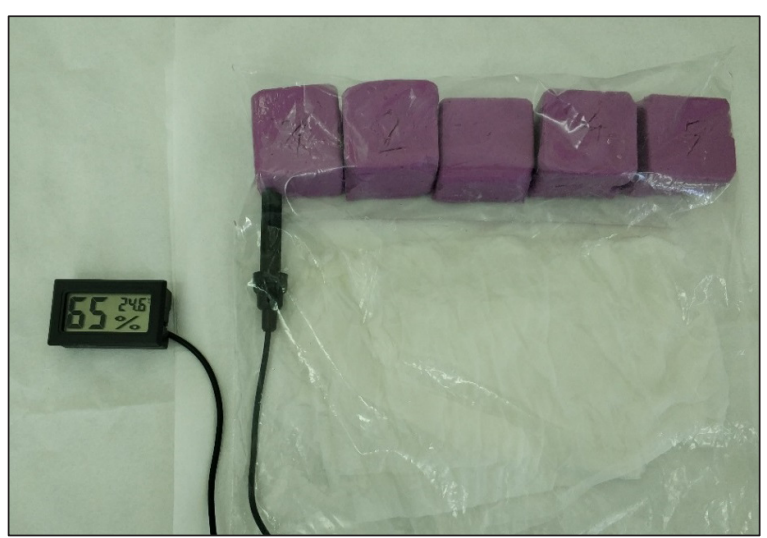

Fig. 3. Temperature and humidity measurement using a hytherograph with moving measuring head. Ryc. 3. Pomiar temperatury i wilgotności przy u̇yciu termohigrometru z ruchoma glowica.

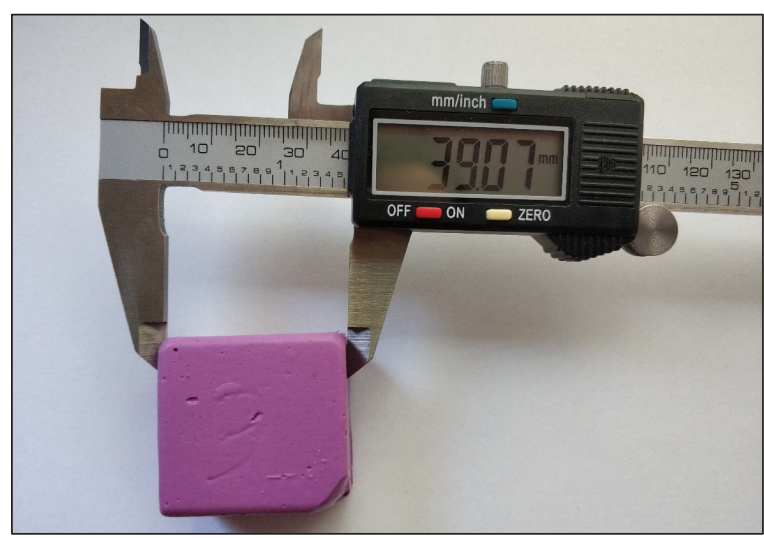

Fig. 2. Dimensions measurement using an electronic vernier caliper.

Ryc. 2. Pomiar przy użyciu elektronicznej suwmiarki.

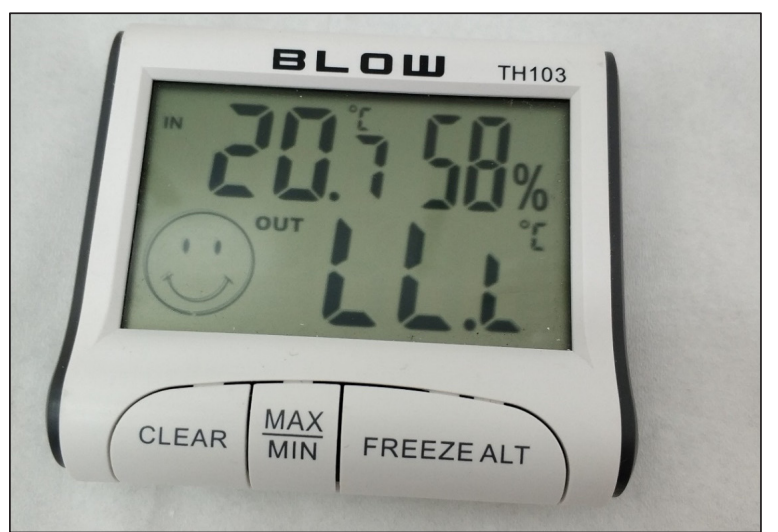

Fig. 4. Measurement of temperature and humidity of surroundings - digital stationary hytherograph BLOW TH103.

Ryc. 4. Pomiar temperatury $i$ wilgotności otoczenia - cyfrowy termohigrometr stacjonarny Blow TH103.

Ta b le 1. Storage conditions of the examined samples / Warunki przechowywania badanych próbek

\begin{tabular}{|c|c|c|c|c|c|c||}
\hline & \multicolumn{2}{|c|}{ Temperature } & \multicolumn{5}{c||}{ Humidity } \\
\hline Groupa & $24.4^{\circ} \mathrm{C}$ & $7.5^{\circ} \mathrm{C}$ & $100 \%$ & $65 \%$ & $43 \%$ & $32 \%$ \\
\hline I & & + & + & & & + \\
\hline II & & + & & & & + \\
\hline III & + & & + & & & \\
\hline IV & + & & & & & \\
\hline V & + & & & + & & \\
\hline VI & & + & & + & \multicolumn{3}{c||}{ Desinfectant solution } \\
\hline VII & + & & $+*$ & $+^{*}$ & \multicolumn{3}{c||}{ Desinfectant solution } \\
\hline VIII & & + & &
\end{tabular}

* Próbki przechowywane w roztworze środka dezynfekcyjnego. 
Ta b le 2. Change of the dimensions of the examined samples / Zmiany wymiarów badanych próbek



hytherographs: Selty AA5B with moving measuring head and stationary Blow TH103 (Fig. 3, 4). The cubes were stored under the following conditions (Table 1).

Group I - submerged in water (humidity $100 \%$ ), at temperature reduced to $7.5^{\circ} \mathrm{C}$

Group II - without increasing the humidity (humidity $43 \%$ ), at temperature reduced to $7.5^{\circ} \mathrm{C}$

Group III - immersed in water (humidity $100 \%$ ), at room temperature of $24.4^{\circ} \mathrm{C}$

Group IV - without increasing humidity (32\% humidity), at room temperature of $24.4^{\circ} \mathrm{C}$

Group $\mathrm{V}$ - in increased ambient humidity (humidity $65 \%$ ), at room temperature of $24.4^{\circ} \mathrm{C}$

Group VI - in increased humidity (humidity $65 \%$ ), at temperature reduced up to $7.5^{\circ} \mathrm{C}$

Group VII - in a disinfectant solution, at room temperature of $24.4^{\circ} \mathrm{C}$ zmierzone za pomocą elektronicznej suwmiarki, o dokładności pomiaru $\pm 0,02 \mathrm{~mm}$ (ryc. 2). Warunki przechowywania - wilgotność, temperatura pokojowa oraz temperatura w lodówce, kontrolowane były przez dwa cyfrowe termohigrometry - Selty AA5B z ruchomą głowicą pomiarową oraz stacjonarny Blow TH103 (ryc. 3, 4). Kostki przechowywane były w następujących warunkach (tab. 1).

Grupa I - zanurzone w wodzie (wilgotność $100 \%$ ), w obniżonej temperaturze do $7,5^{\circ} \mathrm{C}$.

Grupa II - bez zwiększenia wilgotności (wilgotność $43 \%$ ), w obniżonej temperaturze do $7,5^{\circ} \mathrm{C}$.

Grupa III - zanurzone w wodzie (wilgotność $100 \%$ ), w temperaturze pokojowej $24,4^{\circ} \mathrm{C}$.

Grupa IV - bez zwiększenia wilgotności (wilgotność 32\%), w temperaturze pokojowej $24,4^{\circ} \mathrm{C}$. 
Group VIII - in a disinfectant solution, at temperature lowered to $7.5^{\circ} \mathrm{C}$

After $24 \mathrm{hrs}$ and $144 \mathrm{hrs}$ ( 6 days) measurements of cubes were taken by the same operator, using the same tool and taking into account the same measuring sites and. Statistical analysis of the obtained results was carried out using descriptive statistics, specifying maximum, minimum and average values, and with Kruskall-Wallis test.

\section{Results}

Based on the conducted study, the lowest mean dimensional change after 24 hours was found in the group of samples stored at a reduced temperature and humidity of $65 \%$. Measurements after 6 days showed storage at the same humidity, but at room temperature, to be the best if the original dimensions of the samples are to be preserved. The largest dimensional change was noted during the storage of alginate mass without increasing the ambient humidity, as well as in the alcohol-based solution of the disinfecting liquid. In order to determine the significance of differences between all the examined groups, a Kruskall-Wallis statistical test was performed, in which, for the assumed significance level of $\alpha<0.05$, a statistically significant effect of storage conditions on the size change of samples from alginate mass was demonstrated. Dimensional change values for all groups have been presented in the form of a histogram (Tab.2)

\section{Discussion}

According to the study, storage conditions of the alginate impressions have a vast influence on their spatial dimensions and thus the ability to accurately replicate the prosthetic field. In the daily practice, prosthetic laboratories are rarely found near the dentist office, therefore, the need for storage of the alginate impressions
Grupa V - w zwiększonej wilgotności otoczenia (wilgotność 65\%), w temperaturze pokojowej $24,4^{\circ} \mathrm{C}$.

Grupa VI - w zwiększonej wilgotności otoczenia (wilgotność 65\%), w obniżonej temperaturze do $7,5^{\circ} \mathrm{C}$.

Grupa VII - w roztworze środka dezynfekcyjnego, w temperaturze pokojowej $24,4^{\circ} \mathrm{C}$.

Grupa VIII - w roztworze środka dezynfekcyjnego, w temperaturze obniżonej do $7,5^{\circ} \mathrm{C}$

Po upływie 24 h i 144 h (6 dni) zostały wykonane pomiary wymiarów kostek, przy pomocy tego samego narzędzia, z uwzględnieniem tych samych miejsc pomiarowych, pomiarów dokonywał ten sam operator. Przeprowadzono analizę statystyczną uzyskanych wyników stosując statystykę opisową, określającą wartości makł symalne, minimalne oraz średnie, a także przy użyciu testu Kruskalla-Wallisa.

\section{Wyniki}

$\mathrm{Na}$ podstawie przeprowadzonego badania stwierdzono najniższą średnią zmianę wymiarów po 24 godzinach w grupie próbek przechowywanych w obniżonej temperaturze i wilgotności $65 \%$. Pomiary po 6 dniach wykazały przechowywanie w tej samej wilgotności, ale w temperaturze pokojowej, jako najlepszej dla zachowania pierwotnych wymiarów próbek. Największa zmiana wymiarów została odnotowana podczas przechowywania kostek wykonanych z masy alginatowej bez zwiększania wilgotności otoczenia, jak również $\mathrm{w}$ alkoholowym roztworze płynu dezynfekcyjnego. W celu określenia istotności różnic pomiędzy wszystkimi badanymi grupami, wykonano test statystyczny Kruskalla-Wallisa, w którym dla przyjętego poziomu istotności $\alpha<0,05$, wykazano statystycznie istotny wpływ warunków przechowywania na zmianę wymiarów próbek z masy alginatowej. Wartości zmiany wymiarów dla wszystkich grup zostały przedstawione w postaci histogramu (tab. 2). 
for some time before delivery to obtain the plaster cast is inevitable. Because of this fact, it is important to determine and have knowledge of the appropriate storage conditions which will be optimal for the given impression mass. It will mean fewer inaccuracies in the laboratory stages and the final work prepared by the technicians.It will also decrease the need of numerous corrections or even re-doing of the prostheses, which entails economic losses. Performed study and data from the literature indicate a wide range of obtained changes of impression dimensions from alginate mass and the impact of more than one factor on these results. The authors of this work obtained results correlating with data available in the literature. Research by Aalaeia et al. showed the stability of alginate impressions stored in conditions of increased humidity after 24 hours; Sedda et al., in turn, demonstrated significant effect of time (120 hours) of storage samples made of alginate mass on their spatial dimensions. However, the authors point to the insufficient number of studies concerning the impact of alcohol-based disinfectant solutions on alginate mass. $5,10-12$ The obtained results significantly impact the way procedures are performed in everyday practice. It follows that in further consideration it is important to specify a detailed proceeding with the taken impression, namely the right temperature and humidity of its storage. Further research into proper disinfection of the impression should also be taken into account, considering other than alcohol-based disinfectants. Based on the above information, it is clear that it is extremely important to continue the study and include alginate masses of other producers to determine the optimal storage period that would guarantee the best prosthetic field reconstruction and to define precisely the impact of individual variables on the preservation the original dimensions of the tested material.

\section{Dyskusja}

Jak wynika z przeprowadzonego badania, warunki przechowywania wycisków alginatowych mają duży wpływ na ich wymiary przestrzenne, a co za tym idzie na zdolność do dokładnego odwzorowywania pola protetycznego. W codziennej praktyce lekarza dentysty rzadko spotyka się pracownie protetyczne przy gabinetach, zatem konieczność przechowywania przez pewien czas wycisków alginatowych przed dostarczeniem ich do odlania modeli z gipsu jest nieunikniona. $Z$ tego powodu tak ważne jest dokładne określenie i znajomość właściwych warunków przechowywania najbardziej optymalnych dla danej masy wyciskowej. Przekłada się to na zmniejszenie niedokładności etapów laboratoryjnych i wykonywanych przez techników prac, a także konieczności licznych poprawek lub wręcz ponownego wykonywania prac protetycznych, co niesie za sobą straty ekonomiczne. Przeprowadzone badanie i dane z piśmiennictwa wskazują na dużą rozpiętość uzyskanych wartości zmian wymiarów wycisków z masy alginatowej, a także wpływu więcej niż jednego czynnika na te rezultaty. ${ }^{6}$ Autorzy obecnej pracy w przeprowadzonym badaniu uzyskali wyniki korelujące $\mathrm{z}$ dostępnymi $\mathrm{w}$ piśmiennictwie danymi. Badania Aalaeia i wsp. wskazały na stabilność wymiarów wycisków alginatowych przechowywanych w warunkach zwiększonej wilgotności po 24 godzinach, z kolei w pracy Sedda i wsp. wykazano istotny wpływ czasu 120 godzin przechowywania próbek wykonanych z masy alginatowej na ich wymiary przestrzenne. Autorzy zwracają jednak jednocześnie uwagę na niewystarczającą liczbę badań odnośnie wpływu alkoholowych roztworów dezynfekcyjnych na masę alginatową ${ }^{5,10-12}$ Uzyskane wyniki w znaczący sposób wpływają na postępowanie w codziennej praktyce. Wynika z tego, że istotne w dalszych rozważaniach jest określenie szczegółowego toku postępowania z pobranym wyciskiem, odpowiedni zakres temperatury i 


\section{Conclusions}

1. Increased humidity ensures the smallest change of the dimensions of impressions taken using alginate mass.

2. Lowering the storage temperature positively influences the dimensions of the tested samples.

3. Alcohol-based disinfectants should not be used for storing alginate impressions because they reduce the size of the tested samples. wilgotności jego przechowywania. Uwzględnić należy również dalsze badania nad prawidłową dezynfekcją wycisku, rozważając inny niż alkoholowy środek do dezynfekcji. ${ }^{13,14} \mathrm{Z}$ powyższych informacji wynika, iż niezwykle ważna jest kontynuacja i włączenie do badania mas alginatowych kolejnych producentów, określenie jak długi okres czasu przechowywania daje gwarancję najlepszego odwzorowania pola protetycznego i precyzyjne określenie wpływu poszczególnych zmiennych na zachowanie pierwotnych wymiarów badanego materiału.

\section{Wnioski}

1. Zwiększona wilgotność zapewnia najmniejszą zmianę wymiarów wycisków wykonanych przy użyciu masy alginatowej.

2. Obniżenie temperatury przechowywania wpływa pozytywnie na wymiary badanych próbek.

3. Roztwory dezynfekcyjne na bazie alkoholu nie powinny być stosowane do przechowywania wycisków alginatowych ponieważ powodują zmniejszenie wymiaru badanych próbek.

\section{References / Piśmiennictwo}

1. Surowiecki D, Wierzba J, Grygoruk $R$, Wróbel-Bednarz K: Analiza stopnia dopasowania mostu protetycznego zaprojektowanego i wykonanego metodami cyfrowymi. Protet Stomatol 2018; 68(1): 32-44.

2. Burzynski JA, Firestone AR, Beck FM, Fields $H W$ Jr., Deguchi T: Comparison of digital intraoral scanners and alginate impressions. Time and patients satisfaction. Am J Orthod Dentofacial Orthop 2018; 153(4): 534-541.

3. Baig MR, Buzayan MM, Yunus N: Accuracy of new elastomeric impression material for complete-arch dental implant impres- sions. Journal of Investigative and Clinical Dentistry, 2018; 9: e12320.

4. Wandrekar S, JuszczykAS, ClarkRK, Radford $D R$ : Dimensional stability of newer alginate impression materials over seven days. Eur J Prosthodont Restor Dent 2010; 18(4): 163170.

5. Aalaei S, Ganj-Khanloo $R$, Gholami F: Effect on storage period on dimensional stability of Alginplus and Hydrogum 5. J Dent (Tehran) 2017; 14(1): 31-39.

6. Kulkarni $M M$, Thombare RU: Dimensional changes of Alginate Dental Impression 
Materials - an invitro study. J Clin Diagn Res 2015; 9(8): ZC98-ZC102.

7. Todd JA, Oesterle LJ, Newman SM, Shellhart $W C$ : Dimensional changes of extended-pour alginate impression materials. Am J Orthod Dentofacial Orthop 2013; 143(4 Suppl): S5563.

8. Ambrose PK, Juszczyk AS, Clark RK, Radford $D R$ : Effect of two different disinfectants on dimensional stability of newer alginate impression materials over five days. Eur J Prosthodont Restor Dent 2011; 19(4): 142145.

9. Babiker GH, Khalifa N, Alhajj MN: Dimensional accuracy of alginate impressions using different methods of disinfection with varying concentrations. Compend Contin Educ Dent 2018; 39(1): e17-e20.

10. Muzaffar D, Braden M, Parker S, Patel MP: The effect of disinfecting solutions on the dimensional stability of dental alginate impression materials. Dent Mater 2012; 28(7): 749755.

11. Alkurt M, Yesil Duymus Z, Dedeoglu N: Investigation of the effects of storage time on the dimensional accuracy of impression materials using cone beam computer tomography. J Adv Prosthodont 2016; 8(5): 380-387.

12. Sedda M, Casarotto A, Raustia A, Borracchini $A$ : Effect of storage time on the accuracy of casts made from different irreversible hydrocolloids. J Contemp Dent Pract 2008; 9(4): 59-66.

13. Samra RK, Bhide SV: Comparative evaluation of dimensional stability of impression materials from developing countries and developed countries after disinfection with different immersion disinfectant systems and ultraviolet chamber. Saudi Dent J 2018; 30(2): 125141.

14. Hiraguchi $H$, Kaketani $M$, Hirose $H$, Yoneyama T: The influence of storing alginate impressions sprayed with disinfectant on dimensional accuracy and deformation of maxillary edentulous stone models. Dent Mater J 2010; 29(3): 309-315.

Zaakceptowano do druku: 27.09.2018 r.

Adres autorów: 02-006 Warszawa, ul. Nowogrodzka 59.

(C) Zarząd Główny PTS 2018. 